\title{
SLC43A1 wt Allele
}

National Cancer Institute

\section{Source}

National Cancer Institute. SLC43A1 wt Allele. NCI Thesaurus. Code C52290.

Human SLC43A1 wild-type allele is located within 11p11.2-p11.1 and is approximately 31 $\mathrm{kb}$ in length. This allele, which encodes large neutral amino acids transporter small subunit 3 protein, plays a role in the transport of large neutral amino acids. Alterations in the gene may play a role in the development of human prostate cancer. 